\title{
Politics and Metaphysics: A Problem in German Philosophy
}

\section{by Chris Thornhill}

\section{First published in Studies in Social and Political Thought 5, 2001.}

Political philosophy in Germany from Kant to the present turns in different ways on a critique of metaphysics - on an attempt either to define the realm of human meanings and validity as independent of metaphysics, or to examine ways in which human praxis and cognition might assume for themselves the powers of self-legitimization which are withheld from human existence in metaphysical or theological conceptions of human being. ${ }^{1}$ From Kant onward, consequently, German political philosophy might also be interpreted as a series of diverse, but related reflections on the problem of humanism. This line of reflection comprises a series of attempts to outline the anthropological specificity of the human, and so to define the human in its difference from (or relation to) originally theological or metaphysical perspectives on humanity.

Underpinning the argument of this essay is the claim that throughout the tradition of political reflection in modern Germany the issue of legality is of crucial significance in the endeavour to formulate a conception of the human, and that law is the key term in which the possibilities of human selfrealization are stated against metaphysics. There are obvious theoretical and historical reasons for this centrality of law in post-metaphysical debate on politics. The justification of political order by metaphysically heteronomous principles might be viewed as a defining characteristic of late-mediaeval religious anthropology, and of its concrete political manifestations in the early-modern state, in which law reflects the limits of human claims to liberty and historical authority. ${ }^{2}$ The great event at the beginning of modern German history and modern German philosophy, the Reformation, also hinged on a partial (albeit ambiguous) secularization of law, or at least on a desire to demarcate worldly power from theologically enshrined obligations. ${ }^{3}$ Very summarily, therefore, it might be argued that the re-ordering of law as a terrain for the articulation of possible human autonomy constitutes a crucial disjuncture in the development of political humanism, or even in the formation of what is more generally identified as political modernity. 
It is on this foundation, in any case, that the most manifest preoccupation of German political philosophy can be identified: namely, the conflict between legality and political legitimacy, and the attempt to establish a relation between these two terms. The quest for legitimate law, for law as something other than a series of residually meta-physical ordinances, is also the quest for the human: for a conception of humanity as a freely selflegitimizing centre of agency. All major perspectives in German political philosophy discuss the conditions under which law might be legitimate, and this discussion always entails a discussion of the conditions (both cognitive and practical) under which the human might be genuinely human. As will be considered below, in addition this discussion also involves reflection on the nature of politics, on the particular composition of politics, and on the relation of politics to law.

Starting with Kant, therefore, German political philosophy begins to reflect thematically on how truth-contents which, in classical-metaphysical or theological positions are considered to be external to the human, can be transposed into the agency of humanity itself. Kant's thought centres on a critique of classical metaphysics which rejects the claims of metaphysical speculation, and which, in its opposition to Humean scepticism, is prepared only to defend a very restricted conception of metaphysics, as a this-worldly metaphysics of ethical and cognitive validity. Indeed, perhaps the most fundamental intention of Kant's philosophy is to account for the form of human validity through a transformation of speculative metaphysics into a metaphysics of humanity itself. In this respect, it is of central importance for Kant's transcendental idealism that he defines human rational cognitive and ethical validity on the foundation of transcendental ideas. ${ }^{4} \mathrm{He}$ explains the transcendental ideas, remotely inherited from Plato, not as elements which are stabilized prior to the fact of human reflection, but as formally regulative principles, which can be both cognitively deduced and practically applied in the operations of pure reason and practical reason. Transcendental ideas, for Kant, are no longer elements of a speculative or metaphysical order: they are unconditioned points of synthetic regress which determine the limits of human meaning, and through which human beings reflect the totality of the conditions of their thought and action. The internal coherence of human thinking and acting thus depends on the extent to which they are consistent with rationally reflected ideas, which form the unconditioned condition of all human meaning and justification.

As Heidegger identified, therefore, in Kant's idealism metaphysics, which initially limited the human, or which categorized elements of being which are not human, enters an intimate association with two sciences concerned specifically with human faculties: namely, with anthropology and 
epistemology. ${ }^{5}$ In both of these sciences, Kant interprets law, or the 'legislatory' function of reason, as the determinant of human validity. ${ }^{6}$ In respect of anthropology, Kant's doctrine of practical reason might be seen to transpose the original elements of metaphysics into a legal doctrine of human self-realization, in which humanity rationally realizes its own human potentials (detaches itself from the natural/mechanical systems of instinctuality and causality) by explaining to itself the founding conditions (ideas) of its justification and validity, and by subsequently complying with these. ${ }^{7}$ In this, Kant outlines a concept of practical-rational agency, in which humanity assumes responsibility for producing and justifying the conditions within which it can give a unitary and internally consistent account of its own possible autonomy. In respect of epistemology, Kant's doctrine of pure reason also proposes a legal model of categorial logic, which ambiguously both validates and revokes metaphysical theories of knowledge: theories of knowledge which separate truth from the conditions of human being. On one hand, he replicates a residually dualist conception of knowledge, which still sustains the metaphysical distinction between the world of ideas and the world of obtainable knowledge, and which indicates that certain questions (for instance, the question of God's existence) cannot be adequately posed or answered within the constraints of the validity of human reason. On the other hand, however, he also proposes a theory of knowledge in which human cognitive processes can legislatively engender a unity of valid meaning, which permits the synthetic interpretation of possible objective experience, ${ }^{8}$ and which thus replace speculative-metaphysical modes of inquiry with intelligible systems of knowledge. In both sciences of the human, therefore, the human is circumscribed as a centre of reasonable legislation, which can give a consistent representation of its own practical and cognitive validity.

Even in the Critique of pure Reason, however, Kant already implies (however cautiously) that practical reason has a certain primacy over pure reason in the transposition of prior metaphysical unities of cognition and ethics into the internal structure of autonomously human agency. The 'principles of pure reason,' he states, 'obtain objective reality in their practical, and particularly their moral usage' ${ }^{9}$ On this basis, Kant argues that practical reason is a modality in which the unconditioned principles of human reason can form an objective world of validity, in which reason translates its primary meta-physical ideas into the principles (laws) of a meaningful reality. Consequently, if pure reason limits human reason against metaphysics, practical reason in some respects shows how human reason can produce its own concrete reality as consistent with metaphysical ideas. These ideas then become laws, and laws are the terms in which human reason places itself in coherent unity with its determining principles. 
Kant's attempt to ground human autonomy in the acts of selflegislation of practical reason remains, however, antinomical: that is, it opposes the sphere of law's deduction and value to the sphere of its application. Indeed, although clearly intended as a humanist critique of metaphysics, Kant's idealism might be seen merely to recreate metaphysics as a formal-ethical doctrine of human self-realization, in which the condition of realized humanity is stratified, as a formally intelligible system of valid meanings and prescriptions, against the local experiences of human existence and the historical possibilities of human freedom. It is for this reason, therefore, that it is commonly alleged (at least within a historicist line of critique) that Kant's humanization of metaphysics, and his location of human truth in human self-legislative autonomy, is a false humanization, which can only account for human autonomy on grounds which are still metaphysical. Although Kant argues that human consciousness and human praxis can act in accordance with their own unitary foundations, these foundations, supposedly the preconditions of human-being, are placed in a relation of abstract intelligibility towards the particular nexi of being. Consequently, the models of ethical praxis and categorial cognition which Kant deploys have left themselves susceptible to the accusation that they merely reconstitute metaphysics as a science of the human, which remains indifferent to the experiential and historical diversity of human-being, which neglects the difference of human beings from one another at the level of particular thought and experience, and which, crucially, formalizes human freedom by defining liberty as necessary adherence to transcendentally ethical principles.

The implications of Kant's metaphysical anthropology for political theory pull in different directions. In intention, Kant seeks to provide for a concept of politics which defines the legitimacy of a political order in categories which directly replicate his underlying anthropology. This means that, for Kant, the polity becomes legitimate insofar as it accords with universalizable ideas and thus detaches itself from the sphere of natural instinct and antagonism, which is characterized both by obedience to nonreflected laws of causality and by the pursuit of purely private motives. ${ }^{10}$ The genesis of political legitimacy is therefore defined as the moment in which private or natural modes of interaction are replaced by (or translated into) rationally and publicly agreed universalizable laws. ${ }^{11}$ On a slightly less apparent level, however, Kant's claim that human reason realizes itself by reflecting ideas which can be accepted as universal principles, and which then constitute the foundation for a legitimate order, intimates a subsidiary metaphysical dimension in his political theory, which in some ways contradicts his primary reflections on legitimacy. Kant's apriorism, in fact, provides the basis for the science of private law, as it developed through 
nineteenth-century Germany. ${ }^{12}$ By claiming that the legitimacy of the political order depends upon norms which exist in a subjectively deduced value-sphere which is formally prior to itself, Kant drafts a model of legitimacy which is, in certain respects, based in the defence of private liberties and private interests. This model connects in a complex manner with the line of theoretical contractarianism, which Kant might otherwise be seen to oppose. Although his anthropological universalism seemingly forms the basis for a public-law model of legitimacy, his prioritization of norms over politics also paradoxically privatizes the intended universal foundations of the political order, as it makes public order contingent upon the particular, monadic use of reason. Kantian apriorism constitutes, thus, a metaphysics of early liberalism, which attempts to de-privatize political order and to separate the public body of the state out from the private interests of dynasties, monarchs and armies. However, he also claims that the terms of political legitimacy are generated out of certain pre-established principles of reason, which the polity must defend as the condition of its own legitimacy. The sanctity of private property is central amongst these principles. ${ }^{13}$

Of the greatest importance for this discussion, however, is the fact that at the heart of Kant's anthropology is a limiting of politics by law. For Kant, the legitimacy of political order always relies upon law, and it is defined in relation to legal norms, which are deduced prior to praxis. In essence, Kant argues that legitimacy can only result from legality, that political order becomes legitimate via law, and that legitimacy cannot in any respect be conceived as outside law. This means that political order is legitimate only to the extent that it is still metaphysical, or at least to the extent that it reflects intelligible principles. For all his turning away from classical metaphysical positions, therefore, Kant's perspective might actually be seen as the culmination of scholastic reflection on law, in which law (firstly as divine law, but here as natural law) retains a metaphysical, or intelligible, primacy against the actual specificity of the human. Practically, this grounding of legitimacy in legality means that the conditions of legitimacy are reified against human objective experience, against human historical change and, perhaps also, against the possibility of spontaneous political freedom.

At the heart of Kantianism we thus see a conceptualization of the relation between legality and legitimacy which articulates not only a legal problem, but also a metaphysical argument with far-reaching epistemological and anthropological implications. This argument becomes crucial for subsequent debates in each of these areas. Firstly, in its epistemological consequences, Kant's perspective intimates that legitimate political existence is correlated with a particular way of knowing, in which human reason adequately reflects the extent of its accountability and its 
possibility for freedom. ${ }^{14}$ Political legitimacy is the collective expression of reasoning subjects who know about the world, and about the human position and human obligations in the world, on the foundation of unitary, regulative ideas: legitimacy is the objective reality of reason which has obtained form in laws. ${ }^{15}$ Kant thus implies that the legitimacy of law expresses a prior unity of consciousness, in which human cognition has unified itself with its innermost regulative functions, and so explained to itself the totality of the conditions which enable human cognitive and ethical validity. Secondly, Kant's legal theory also makes an anthropological claim about human praxis: political legitimacy is the objective distillation of modes of practical being, in which humans regulate praxis by ideas (laws), and organize their actions within a formal-ideal (legal) system of intelligible motivations. Kant thus implies that legitimate politics reflects an intelligible unity of consciousness, in which praxis is thoroughly determined by the primary ideas (laws) of human consciousness. ${ }^{16}$ Legitimate politics, consequently, is a condition which synthesizes theory and praxis through the medium of legality. Underlying this is the suggestion, whose subsequent implications cannot be exaggerated, that the legitimacy of political order has as its substructure the cognitive and ethical legitimacy of the human itself. Kant attempts to outline a condition in which human agency is in reflexive unity with the fundamental preconditions of its cognitive and ethical autonomy, and he argues that political legitimacy necessarily results from this condition. Legitimacy is, therefore, the state of valid humanity, and valid humanity, for Kant, proposes itself through the medium of law.

Notably, however, Kant always describes the possible terms of factually legitimate law on the basis of an epistemological unity of consciousness and an anthropological unity of reflexive praxis which can only ever be formally or intelligibly realized: the epistemological and anthropological foundations of legitimacy are conceivable only as an arena of validity in which the operations of human reason are organized in a sphere of value which is closed both to speculation and to historical determinacy. The epistemological and anthropological preconditions of legitimacy are thus always expressed in formal laws, which always precede the specificity of politics, and which always pre-determine the extent of legitimate political freedom. This means, in short, that Kant's concept of legitimate law revolves around a metaphysics of legality. Legitimate law, for Kant, is the objectively realized form of human consciousness, as it is transcendentally united with its innermost (unconditioned) principles. As such, however, legitimacy is the condition of existence in which human reason has reflected the conditions of its meaning and autonomy in the form of law, and in which these conditions are realized as formally other than being 
itself. Heidegger's argument that Kant's epistemology conceives of human cognition and human action in reified terms, which merely reconstitute heteronomous (metaphysical) conceptions of human justification as a statically juridical system of falsely human values and categories, remains, for these reasons, extremely illuminating for Kant's (and Heidegger's own) political theory. ${ }^{17}$

Kant's essentially metaphysical attempt to conceive legitimacy in terms of legality, on the basis of a formally antinomical conception of human consciousness, paves the way for the major political questions of modern German political philosophy. Indeed, the problem which preoccupies all the most important post-Kantian thinkers - Hegel, Weber, Lukäcs, Heidegger, Schmitt and Habermas - is the question of how the identity of theory and praxis and the unity of legality and legitimacy, which are developed in Kant's legal epistemology, might be reconstituted without following Kant's quasi-metaphysical formal method. All of these thinkers in certain respects follow Kant's argument that true legitimacy is a condition of objective knowledge, in which order reflects a realized unity of consciousness; all therefore also follow Kant in imagining true legitimacy as a mode of practical being, in which there need be no conflict between law and order, and in which order will arise from legislative faculties which are embedded in the composition of human reason or human being itself. Despite this, however, all of these thinkers also argue, albeit in very diverse terms, that Kant's fusion of theory and praxis, and of legality and legitimacy, depends upon reified ideas of humanity and legitimacy, which accept human actions as truly human (legitimate) only where they comply with laws which are abstractly (or meta-physically) formalized as an intelligible sphere of value. Kant's attempt to explain legitimacy as humanity thus relies, from subsequent perspectives, on an illusory conception of both legitimacy and humanity. ${ }^{18}$

On this basis, it might be argued that political thinking after Kant alters the balance of priority in the legality - legitimacy and theory-praxis relation as outlined by Kant, and seeks to develop a non- metaphysical conception of human praxis as the ground of legitimacy. If Kant's juridical position can be seen as a culmination (in anthropological recasting) of the priority of metaphysical law over human politics which is proposed in the scholastic-metaphysical tradition, ${ }^{19}$ subsequent perspectives in German political reflection invert this relationship between law and order, and they attempt, in quasi-Aristotelian manner, to foreground a more anthropologically specific basis of agency on which to found positive law. At the risk of excessive schematization, therefore, if Kant places law before politics and formal right before common freedom as the condition of legitimacy, German political reflection after Kant might be seen gradually 
to refigure these relations, and to envision legitimacy as an order of being in which politics escapes its pre-founding by law, and in which political freedom is not determined on the basis of prior concepts of right. On a more practical level, each major juridico-political position after Kant also moves away from private-legal conceptions of political legitimacy toward models of good politics which give priority to public law, or to the commonly mediated synthesis of private and public law. The critique of the metaphysical-anthropological basis to Kantianism thus also envisages a political order which is not anchored in either metaphysically or possessively pre-stabilized properties.

At the heart of the legal-political debate with Kant, or after Kant, is thus a prising apart of the formality of the metaphysics and the anthropology which always underscore the legality-legitimacy relation in his juridical ideas. In each of the major political positions developed either as corrective or contradiction to Kant, we see an attempt to elaborate a concept of legitimacy, in which legitimacy is the origin of legality, not vice versa, and in which the realm of political agency and liberty is given a specific determinacy against metaphysics, and thus against law. In such concepts, however, the authorship of law is not construed as a sequence of purely functional or prerogative operations, and law is not simply levelled into formal positivity. Notably, in fact, each post-Kantian position is flanked by sustained epistemological and anthropological arguments, which seek to show how legitimate (political) law, although no longer a formally deduced order of right, might still act as the signifier of human self-realization and fulfilment. Each post-Kantian position thus describes, against Kant, what manner of collective knowledge might engender the conditions for a legitimate political order, and what manner of collective praxis might give foundation to the legitimate political order. It is in the environment of this complex critique of Kant that the concept of the political acquires such status in German philosophy. In its various articulations - from Hegel to Habermas - the concept of the political describes a way of thinking and a way of acting, in which human existence, emancipated from all prior juridical order, is at liberty to engender the conditions of its fulfilment and practically to determine the horizon of its own self-realization. Whereas Kant posits law as the objective medium of human self-realization, therefore, after Kant politics generally replaces law as the medium of possible human freedom and fulfilment, and law acquires its dignity only where it gives form to practical freedom in politics. Indeed, if Kant's humanism centres on a legal epistemology and a legal anthropology, post-Kantian political thought might be viewed as a series of moves towards the development of a humanism centring on political epistemology and political anthropology. 
Hegel, for instance, clearly implies that Kant's juridical anthropology only serves as the basis for an abstract (and therefore possessive) conception of political legitimacy. Hegel's own philosophy founds political legitimacy on a juridical conception, which interprets legitimacy in law as the historically formed realization of possible human freedom, and which directly opposes the formal universalism, and the priority of abstract right, in Kant's legal theory. ${ }^{20}$ On Hegel's view, legitimate legality cannot be formally or abstractly reified against the determinate historico-political position of its addressees. Instead, legitimate law is articulated through the manifest conceptions of freedom in the practical/ political existence of citizens. Underpinning Hegel's argument for legitimate law is thus an intensely politicized anthropology, in which the realization of humanity is intimately connected with the types of interaction which constitute politics. For Hegel, law is most legitimate where it is most political: where it expresses historical elaborations of freedom, not formal-metaphysical preconditions. Law is consequently most legitimate where it is not abstractly counterposed to the practical values of common life, where it is not formally or negatively tied to private or economic interests, ${ }^{21}$ and where it elaborates conceptions of freedom which are not harnessed to purposes of personal interest, utility or advantage. ${ }^{22}$ Hegel thus rejects Kant's claims for the invariable prepolitical universality of legitimate law, and he attempts instead to elucidate the relatively valid forms of law in their historical and political concretions. Underpinning this theory of legality and legitimacy are two key epistemological and anthropological arguments. Firstly, Hegel outlines a political epistemology as the groundwork for legitimate politics: the composition of legitimacy in politics, he indicates, emerges from a way of knowing in which particular human self-consciousness recognizes its historico-political mediation as the condition of its own liberty, and acknowledges that the possibility of liberty is already inscribed in its historically and politically formed consciousness. ${ }^{23}$ The political, therefore, is ingrained in knowledge itself, and legitimate politics always has its foundation in political knowledge. Secondly, in close relation to this, Hegel also draws out a political anthropology as the foundation of legitimacy. His conception of legitimacy is supported by a concept of praxis which claims that certain modes of human practical interaction engender more organic and cohesive modes of freedom than others, and that the political order derives its legitimacy from its ability to represent those modes of practical being in which the idea of freedom is most richly realized. ${ }^{24}$

Likewise, albeit in very distinct manner, Max Weber also attempts to overcome the formal, private and antinomical relation between legality and legitimacy in Kantianism by attempting to ground his theory of politics in 
an epistemological and anthropological conception of responsibility. Through this term Weber seeks to infuse historical and experiential specificity into Kant's construct of legitimacy. In his opposition of ethical and pragmatic responsibility, he defines a model of political agency which (at least in intention) overcomes the intelligible reification of political ethics in Kantianism by generating political legitimacy on the foundation of historical experience and decisively political rationality. ${ }^{25}$ Weber therefore envisions that the self-constitution of true humanity, no longer formally or functionally subordinate to rational/administrative imperatives, will be realized in the laws of purpose-giving, political responsibility. Indeed, he expressly indicates that responsibility has a crucial anthropological significance, which directly parallels the significance of legality in Kantianism. For Weber, the bureaucratic rationality of modern legal and political systems reflects a nightmarish distortion of Kant's original reflections on law. Kant sees formal-rational law as the cornerstone in a critique of metaphysics, and thus as the foundation for a project of human self-realization and political emancipation. Weber, however, argues that in modern legal, administrative and economic orders the intelligible system of positive law has organized itself against all vitally human relations and meanings, and it serves only to incarcerate human existence and human freedom in a false metaphysics of formal validity and insubstantial purposes. Rather than overcoming metaphysics, Weber implies, Kant's theory of legality as intelligibility has reconstituted itself in modern methods of governance as a technical metaphysics of order, which sustains perniciously depersonalized modes of domination. ${ }^{26}$ The false metaphysics of positive law, therefore, can only be offset by a mode of practical reason, which Weber characterizes as political, and which is capable of freely and decisively generating substantial values and purposes. ${ }^{27}$ Decisive political responsibility is thus, for Weber, an attitude in which human existence freely proposes itself as a truly purposive, truly political, and thus truly human agency. Legitimate laws, consequently, are laws which are formed in this political attitude, and as such they are substantially distinct from modern positive laws, whose customary quality is to act as functional devices for maintaining the operations of the bureaucracy and the economy. ${ }^{28}$

Carl Schmitt also reconstructs the antinomies of Kantianism on the basis of a political epistemology and a political anthropology, through which he seeks to transform pure (metaphysical) legality into a cohesive mode of legitimacy. More even than Hegel and Weber, Schmitt makes elaborate claims for the category of the political as an anthropological and epistemological moment, which overcomes the false-metaphysical formalism of Kant's idealism by practically and spontaneously producing 
law from the concrete situation of the political order, and which thus grounds legitimacy in the unified, homogenous self-knowledge of the people. By seeking to unite legality and legitimacy in the specifically human modality of the political, Schmitt also sets out a most radical critique of the reification of human existence and political knowledge in social orders based in private-legal or formal-rational agreements. It is on this foundation that he so vehemently rejects positivist conceptions of legal universality and neutrality, which have their remote origin in Kant's ideas of contract and obligation. Most especially, however, Schmitt imagines politics as a category of collective freedom, in which the common identity of the community can engender the terms of its own liberty without ordering itself around formal or abstract precepts. ${ }^{29}$

In a certain, albeit oblique, continuity with these positions, Habermas also centres his inquiries into the possible terms of political legitimacy on the basic Kantian problem. He argues for a conception of legitimacy which emphatically rejects the formality of bourgeois private law as the basis of politics, and which thus opposes the classical-liberal stabilization of the conditions of public order at a pre-interactive, pre-discursive or pre-practical (metaphysical) level. ${ }^{30}$ He also proposes terms for a practical/political anthropology and a practical/political epistemology, of which justifiable political order (legitimacy) is the corollary. Habermas's epistemology of politics turns on a cognitive theory which defines truthful knowing as a mode of publicly mediated knowledge, and which explains truth as the result of politically free communication, which founds commonly acknowledged reciprocal obligations. ${ }^{31}$ True knowledge, therefore, is always eminently political, and legitimate laws and legitimate citizenship must ground themselves in such cognitive politicality. ${ }^{32}$ Likewise, Habermas's political anthropology expressly indicates that authentic human-being is quintessentially defined by certain faculties of practically universal interaction and agreement, which, if adequately elaborated, form a unitary basis for political legitimacy. Human truthfulness is therefore always political, and political legitimacy is always the life-form of realized epistemological and anthropological potentials.

In short, the major theories of law and politics set out after Kant might be viewed as attempts to liberate human political agency from metaphysical form. All the above positions seek to illuminate the primary terms of political legitimacy as ways of knowing and acting which are emancipated from classical-metaphysical matrices, and which constitute a basis of realized freedom on which order might be established. In each instance, nonetheless, it might be argued that the antinomical epistemological and anthropological basis of Kant's theory of legitimacy is only inconclusively corrected. Indeed, 
it is arguable that each of these positions still depends on either a manifest or a suppressed metaphysical anthropology.

Hegel is in some respects furthest removed from the original Kantian argument on the priority of legality to legitimacy, and he is therefore perhaps closest to a non-metaphysical concept of political legitimacy. However, his reflections on the legitimacy of law still in some respects rely upon an anthropology which attributes an ideal underpinning to political manifestations of freedom, and which still imputes prior determinations to human agency. For Hegel, some areas of human interaction, for instance those in the economy, are led by abstract or formal considerations of advantage or utility, and these are therefore incapable of providing a basis of shared legitimacy for law. ${ }^{33}$ Others, however, for instance those in the political apparatus and the administration, ${ }^{34}$ are motivated by nonformalized universal resources, and are therefore capable of reflecting a more refined conception of objective freedom. Thus, although Hegel argues that the order of political life can on its own give form to the idea of freedom, and so generate legitimacy in law, this argument hinges on a prior categorization of human interaction, which accords to certain modes of being (and so to certain privileged people) a greater ability to realize substantially binding liberty than to others. ${ }^{35}$ Consequently, although Hegel moves away from the formality of Kant's legality-legitimacy synthesis, he overcomes the priority of law in this relation only by determining the capacity for obtaining and recognizing legitimate law as an invariable moment, which is actively and reflexively realized in those functional arenas in which citizens are determined as political. ${ }^{36}$ The political realization of freedom (legitimacy in law) thus relies on a prior calibration of human action, which simply identifies certain modes of acting and knowing as legitimately legislatory. Hegel therefore does not persuasively correct Kant's antinomical conception of legality and legitimacy, and he does not detach political legitimacy from its juridical basis.

In analogous manner, it might be argued that Weber, Schmitt and Habermas are all variously unable to construct an epistemological or anthropological model of politics which might give substance to a decisively post-Kantian concept of legitimacy. Weber's epistemology, for instance, never finally dislocates itself from the quasi-essentialist principles of Kantianism. His anthropology projects the possibility of truthful politics only on the basis of a prior typology of human attributes, of which only charismatic reason can create non-formal laws, and so constitute the foundation of true politics. Political legitimacy, although the form and content of freedom, is thus produced by pre-political resources of human character, which provide an entitlement for legislation. ${ }^{37}$ In addition, Weber's 
theory of responsibility restricts the source of charismatic legitimacy to certain specially gifted and trained political and plutocratic elites, and it imagines legitimate law-creation as the domain of certain elevated charactertypes, effected in the skilfully administered nation-state. Although Schmitt makes the most effusive epistemological and anthropological claims for that unique way of knowing and acting which he conceives as political, this too is always underpinned by a strong (yet suppressed) debt to the core Kantian principles. ${ }^{38}$ Despite his sporadic closeness to extreme historicist perspectives, Schmitt generally argues that legality is legitimate (i.e. that it becomes something more than formal positivity) only insofar as it conforms to or represents ideas: legitimacy in law thus depends on law's capacity to indicate certain ethical principles, which cannot be distilled either from the private interests of social agents or from the functional needs or concretepractical orientations of the political apparatus, ${ }^{39}$ and which are thus in some way metaphysically prior to the political. ${ }^{40}$ Whatever his party-political allegiances and collusions, therefore, Schmitt's thinking overlaps directly with the anthropological underpinning of liberalism, which he otherwise (at least in gesture) deplores. Indeed, Schmitt might easily also be viewed as an authoritarian Kantian thinker who endorses a model of executive democracy which is in some respects close to that originally espoused by Kant. Both Weber and Schmitt, in any case, project the decision of particular political subjectivity as a key element in a post-metaphysical anthropology, in which human political agency spontaneously overcomes the difference between legality and legitimacy, and so creates legitimate law through its own resources of decisive responsibility. As long as it is decisive, both imply, law is always legitimate. Such decisiveness, however, is founded in attributes which are always endowed with legislative authority, and the theory of the decision cannot therefore account for political freedom as a genuinely independent region of human activity.

In similar manner, Habermas too is not finally conclusive in his attempt to ascribe a non-formalized (political) substructure to the legal order of the modern state, and he too relies extensively on a humanist anthropology, which always divulges its metaphysical genesis. It is naturally fatuous to accuse Habermas of being a closet Kantian, when he always expressly recognizes the clear Kantian components in his thinking. However, it might be observed in the case of Habermas - as in that of Hegel, Weber and Schmitt - that the attempt to overcome the Kantian circumscription of legitimacy by legality always hinges on a model of human agency which is itself primarily antinomical (or metaphysical). Habermas expressly insists on the political quality of legitimate law, and he claims that law which is deduced prior to political discourse cannot actively shape the political 
identities of citizens. Legitimate law, thus, must result from political agreements which are co-original with their legal formalization. This is obviously the crux of his mild invectives against Rawls. ${ }^{41}$ However, Habermas arrives at his conception of legitimate law by arguing that the participants in political discourse are always anthropologically oriented towards legally binding consensus, and that law (unlike the technical media of administration and financial exchange) can always communicatively transform private interests into commonly acknowledged and internalized political obligations. ${ }^{42}$ For this reason, it might be argued that Habermas only secures the political moment in law (its legitimacy) by a rather tautologous sleight of hand. His claim that legality and legitimacy can be reconciled through public/political discourse and that such discourse can always form a basis of legitimacy for legality is sustained only because he also indicates that discourse itself always has an internally juridical structure. If it is not disrupted by technical interventions, he indicates, discourse is always directed towards universally binding agreement, always articulates the consensus-seeking dimension of human practical reason, and therefore always produces legitimate laws. Discourse, therefore, is always juridical, and the political (legitimate) content of laws is obtained on the basis of an apriorist anthropology, which predetermines certain arenas of human interaction as inherently predisposed towards legitimate law-giving. Habermas thus establishes the condition of legitimate legality not through, nor after, but in fact before politics itself. ${ }^{43}$ The antinomical character of Kantian political theory is thus not overcome by Habermas. Rather, Habermas side- steps the problems of Kantianism by arguing that human practical reason, in certain anthropologically specific (non-technical) contexts, is endowed with invariable resources for the creation of legitimate law: such law, however, can only be applied to anthropologically specific (non-technical) regions of human operation. Thus, although Habermas believes that he overcomes the formal synthesis of legality and legitimacy in Kantian philosophy, and that he succeeds in explaining how legitimate law can be produced out of (not prior to) human political praxis, this is in fact not the case. In Habermas's thought, political legitimacy originates not in political discourse, but in a juridical anthropology, which abstractly predefines certain ways of thinking and acting as intrinsically oriented towards legitimate law-creation.

In sum, therefore, it might be argued that the attempts to supersede Kantian juridico-political positions undertaken by Hegel, Weber, Schmitt and Habermas all fail. In fact, all fail for essentially similar reasons. In each case, the prior unities of consciousness and praxis which underpin Kant's metaphysical fusion of legality and legitimacy are simply transformed into 
prior resources of human agency, which form the basis for an anthropological (or political) fusion of legality and legitimacy. These moves against Kant, however, do not overcome the foundation of legitimacy in metaphysical attributes: they simply conceive of legitimacy as an expression of certain human properties, whose capacity to produce legitimate laws is always presupposed. Indeed, these moves against Kant do not circumvent either the founding of legitimacy in legality, or the founding of the human in law. Legitimacy remains the concrete expression of a pre-political disposition towards legislation, which in itself defines the constitution of the human. The most widely-criticized feature of Kant's fusion of legality and legitimacy is the postulation of a possible unity of human consciousness and human praxis, which can give prior order to political agreements. However, subsequent critiques of Kant also posit - at least implicitly - a pre-political unity of consciousness and praxis, and they too explain legitimacy on the foundation of a juridical conception of the human. In such critiques, however, the legislative ground of the human is not transcendentally deduced or reflexively validated: it is already given, at least latently, as an unreflected element of a practical anthropology.

On this basis, it might equally be asserted that the chief practical intention of these post-Kantian positions - the replacement of the Kantian primacy of private law with a conception of political legitimacy in which the legal order is not anchored in particular interests, but in authentically universalizable agreements or publicly acknowledged principles - is also not convincingly accomplished. Despite criticizing the formal primacy of contract law in the modern economy, Hegel himself suggests that one key function of politics is that the political order stabilizes property interests. ${ }^{44}$ Despite condemning the formal materialization of law under the conditions of capitalist-bureaucratic domination, Weber still ultimately construes political responsibility (or political rationality) as the aptitude for representing private-legal interests in international conflict and competition. ${ }^{45}$ Despite his polemics against the fragmentation of political ethics under the corrosive influence of private-legal positivism, Schmitt finally proposes a tokenist concept of politics, crystallized in the bureaucratic executive, which grants maximum autonomy to the sphere of private-legal interest. ${ }^{46}$ The early Habermas claims, in quasi-Marxist manner, that there exists an irreconcilable conflict between capitalism and legitimate democracy, and that under the conditions of late capitalism law merely translates non-universalizable economic (private-legal) interests into the media of public authority. However, the later Habermas also finally settles for the argument (consistent with his anthropological position) that the legitimacy of law cannot concern itself too extensively with matters of 
exchange or administration, ${ }^{47}$ and that legitimate law has a common anthropological source which is never absolutely obscured by the means of systemic or economic coercion. ${ }^{48}$ In each of these cases, therefore, a metaphysical-anthropological premise is developed, which rejects the formal priority of law in the legality-legitimacy synthesis as it is proposed by Kant, but which nonetheless conceives of the legitimately law-giving aspect of human life in essentialist, invariable and private terms. Despite the postKantian shift of focus from the metaphysically anthropological to the (at least in intention) non-metaphysically anthropological, the perspectives examined above only succeed in connecting legality and legitimacy by recruiting the assistance of an anthropologically apriorist reconstruction of legitimacy.

The most radical assault on the formal basis of Kantian epistemology, juridical philosophy and universalist humanism is articulated in antagonistic parallel by Georg Lukács and Martin Heidegger - two thinkers who are not automatically associated with legal or political discourse. Lukács and Heidegger are united, across the great party- political gulf between them, by their attempt to construct a model of truthfully human agency which, especially in epistemology and practical ethics, rejects all formalmetaphysical or idealist residues as false intrusions in the historical operations of practical being. Heidegger's Dasein, like Lukács's concept of subject-object identity, proposes models of acting and thinking in which theory and praxis are no longer antinomically distinct elements, but are absolutely united in the practical process (Vollzug) of being. Overlying these attacks on the metaphysical legacy in Kantian epistemology is also, however, a theory of political legitimacy. Neither Heidegger nor Lukács would be especially happy with this reception of their work as political reflection. As a communist, Lukács would presumably reject the term 'politics' altogether, whilst Heidegger might at most see politics as a shorthand way of describing historical processes of foundation and national self-organization. However, on some level both set out an important anti-Kantian perspective on collective cognitive and practical agency, which might otherwise be seen as political. Indeed, Heidegger and Lukács might both be viewed as philosophers who pursue the anti-metaphysical associations of politics (together with its epistemological and anthropological substructure) and humanity to their most consistent conclusions. The legitimacy of human organization, both Lukács and Heidegger intimate, is engendered at that moment where all its normative components (all false extrapolations of ideas from agency) are eradicated. Both thus claim that political legitimacy is immediately and non-reflexively guaranteed wherever human cognition overcomes its formally reified position towards the facts of experience, and where human agency surmounts its division through intelligible values and 
abstract norms. So both construe political legitimacy as a condition in which collective action and reflection produce the criteria of their own validity, without imposing any universal standard upon themselves. Political legitimacy, in short, is the form of common human freedom, in which human historical being is cognitively and ethically at liberty to shape itself into integrally valid objective orders of existence.

In short, both Heidegger and Lukács indicate that true human consciousness - as Dasein, for Heidegger, or as the mediated subject/object, for Lukács - is ceaselessly engaged in elaborating itself as a historically realized, collective agency, in which cognition and action are not located in atomized subjective centres, and which provides an invariable common foundation for the legitimate political order. Even in Being and Time, where Heidegger deliberately gives rise to the fiction that he wishes to offer an individuated, existential account of Dasein, he still suggests that Dasein produces meaning only in the nexi of historically formed interactions, and that Dasein can only reflect its own particular properness, authenticity, actuality or essentiality (Eigentlichkeit) by confronting itself with the foundations of its commonly engendered historicity. ${ }^{49}$ Consciousness which has organized itself as the concretely unifying foundation of history, therefore, is legitimacy - and there are no terms for speaking about legitimacy outside of such consciousness. Most importantly, the realized unity of historical consciousness (Dasein or the subject/object) does not need to separate itself into laws: by fusing theory and praxis, historical consciousness dispenses with laws, for it cannot account for a situation in which a law might be theoretically or normatively held as a measure against praxis, or in which the legitimacy of praxis might require any degree of theoretical (legal) validation. For both Heidegger and Lukács, thus, the founding of legitimacy in the overcoming of formal epistemology also entails an overcoming of law. Lukács expressly emphasizes that the unification of thought and action in the subject/object of the proletariat will lead to a thorough reorganization of the formally prescriptive quality of modern law. ${ }^{50}$ Heidegger also repeatedly laments the reified intelligibility of modern law, which he sees as a debilitating residue of Platonist metaphysics and Kantian epistemology, ${ }^{51}$ and in his early writings and lectures he intimates the possibility of re-founding law in the vital and local expressions of grace, proclamation and historically circumscribed decisiveness. ${ }^{52}$

Following the schematic arguments on metaphysics, anthropology and epistemology set out above, therefore, Heidegger and Lukács might in certain respects be seen to give extreme form to the political liberation of anthropology from metaphysics. Both seek to dictate how human being, in politics, might overcome the traumatic alienation which it has suffered 
through metaphysical tyranny (Heidegger) or bourgeois epistemology (Lukács). Both also seek, on this foundation, to explain how human consciousness can produce historically concrete modes of legitimacy, which need no recourse to prior legality, or to conceptions of human character which define the conditions of humanity in heteronomous categories. Most crucially; however, both attempt to conceive of human truthfulness by defining integral human-being as a quality of thinking and acting agency in history, which moves within this history - either in radical political overthrow (Lukács), or radical political acquiescence (Heidegger) - in accordance with its own unitary (non-juridical) political consciousness. So both Lukács and Heidegger propose a political anthropology in which politics and history are equivalent regions of human liberty and self-creation. In addition, both also outline the terms for a political epistemology (or counter-epistemology), in which human thinking freely belongs with human praxis, and is collectively engaged in the developments of common historicality. For both Lukács and Heidegger, consequently, thinking is dislocated from its Kantian juridical basis, and it is recast as a reflex within the practical substance of the people (or the class) in its self-creating histories. This practical/cognitive substrate of class-history or national history usually viewed as 'thinking' - becomes the foundation of political legitimacy.

Both Heidegger and Lukács thus follow the general post-Kantian attempt to provide a new epistemological and a new anthropological foundation for political legitimacy. Both assert that political legitimacy arises from a certain truly human way of knowing, which is mediated with objective modes of historical experience and praxis, and from a certain truly human way of being, which is polymorphously engaged with history. Both also indicate, in however politically diverse terms, that conceiving of legitimacy as the distillation of cognitively deducible (metaphysical) or essentialist (anthropological) properties necessarily incorporates a moment of violence towards the historical spontaneity of the human, and the possible freedom of human self-realization. This, naturally, does not in any way imply that either Heidegger or Lukács can be recruited to a conventional programme of political pluralism or voluntarism (although this reading of Heidegger seems to be catching on). However, both reproach transcendental idealism, especially in its liberal implications for theories of legitimate order, for imposing abstract and reified categories on human cognition and action, and thus for neglecting the freely self-forming, historically immanent, and thus spontaneous character of truthful human political existence. Wherever legitimacy is conceived on the foundation of universally reified laws, both indicate, human-being (legitimacy) is not permitted freely to be and freely 
to act in its own historical situation, but it is always restricted and divided into abstract functions through quasi-metaphysical categories. Truthful humanity (legitimacy) is, thus, the end of reification, and the end of intelligible law. It is in Lukács and Heidegger, not Schmitt, therefore, that we encounter the radical counter-point to liberal-humanist anthropology and liberal-humanist theories of legitimacy. ${ }^{53}$

However, for the purposes of this discussion, two very significant points emerge from these perspectives on Lukács and Heidegger. Firstly, both Heidegger and Lukács see themselves as true humanists, who reject the false reification of human attributes in Kant's own version of humanism, ${ }^{54}$ and who thus champion a vision of the human as realized historical freedom. Nonetheless, it might be argued that the abrogation of all metaphysical elements in the political theories of Lukács and Heidegger ultimately leads to an outline of legitimately historical/political being in which neither history nor legitimacy are in any obvious way either particularly free or particularly human. The legitimately human place of cognitive and practical being, once separated from its antinomical foundations, becomes a mere closed immanence, in which theory and praxis are identical, in which truthful knowledge is validated by the historicality of its situation, in which the legitimacy of law is transposed onto foundations which are not susceptible to normative debate, and in which good order is always the objectively formed life of the collective..$^{55}$ On this basis, the political overcoming of the metaphysical, in thinking and acting, is also the political overcoming of all sustainable conceptions of the human (or at least of the human as a specific condition of accountability and self-justification). In attempting to define the unitary epistemological and anthropological basis of political legitimacy by renouncing all invariable metaphysical or cognitive categories, Heidegger and Lukács thus actually arrive at a conception of political legitimacy which is in every respect significantly less spontaneous, and clearly less free, than the supposedly tyrannical metaphysical/bourgeois orders for whose overthrow they campaign. A similar point might also be raised about the more recent model of legitimacy, also based in a radical unity of theory and praxis, which has been developed by Niklas Luhmann. Like Lukács and Heidegger, Luhmann also claims to serve the interests of a society which is not centred on prior norms or immutable structures, but which spontaneously generates inner pluralities of meaning. He too, however, also sees such plurality best expressed in a strong, indifferent political executive. Indeed, in certain respects Luhmann's functionalist institutionalism might be viewed as a latter-day counterpart to Heidegger's doctrines of objective form. ${ }^{56}$

Secondly, it might also be argued that Heidegger and Lukács only 
attain their goal of overcoming the political principles of Kantianism and post-Kantianism because they shift the foundation of law-giving legitimacy from the reflexive or pre-reflexive subject to the political collective (either as Dasein or the subject/object). Indeed, the unity of theory and praxis as proposed in Heidegger's Dasein and in Lukács's identical subject/object in many ways simply replaces Kant's transcendental subject with the thisworldly universality of the Volk or the proletariat, both of which are conceived as the unshakeable source of legitimacy. Kant imagines legitimate politics as rooted in internally consistent practical and epistemological consciousness, which is ideally (or subjectively) constituted before politics. Heidegger and Lukács attempt to overcome this perspective by conceiving of legitimacy as a quality produced in (or as) politics, as the result of a historically unified and practically consistent consciousness. This consciousness, however, is always realized in the objective orders of people or class, and it thus also possesses a clear objective priority before the plural events of political existence. Heidegger and Lukács are therefore not successful in their attempt to overcome political metaphysics and to create a system of non-metaphysical political legitimacy. They succeed only in effecting a shift from an ideal metaphysics of legitimacy towards an objective metaphysics of legitimacy, in which, however, the political source of legitimacy is still positioned antinomically, or heteronomously, against the plurality of historical experience.

On this basis, a far-reaching claim can be made: namely, that, of all these various attempts to indicate specific ways of human knowing and being which might produce legitimate order as something more than the expression of pre-stabilized properties, or as heteronomous compliance with an objectively realized order of values, none are successful, that all these attempts to account for political legitimacy without recourse to a prior underpinning thus remain inconclusive. Hegel, Weber, Schmitt and Habermas all - however diversely - still conceive of the anthropological and epistemological determinacy of political legitimacy in a manner which only defines politics as an operation which occurs on the basis of prior and independently acquired legislative faculties. The radical break with idealist (or juridical) political metaphysics, which is intended by Heidegger and Lukács (and Luhmann), does not in reality break with metaphysics: it simply transposes the normative dignity of the transcendental subject into the antinormative authority of objectively formed order. It is difficult to see how either Lukács or Heidegger succeed in overcoming the problem of heteronomy except through a spurious reconciliation of particular life to objective form. The attempt to envision political legitimacy as a radically post-juridical order thus still fails to provide a convincing explanation of 
politics as a genuinely free-standing area of human liberty. On close scrutiny, in sum, it might be observed that in not one of these instances does politics finally loosen its metaphysical ties, and that the quest to define legitimate law as the outcome of political life turns either on a metaphysics of law or on a metaphysics of politics. The juridical structuring of politics in Kantian philosophy is therefore never superseded.

These reflections might provide the basis for a series of distinct conclusions regarding the relation between legality and legitimacy, the nature of the political, and the nature of the human. Firstly, one immediate conclusion in these questions would be that drawn by Nietzsche, and in some respects by Adorno: namely, that the attempt to identify the conditions of human liberty is deeply misguided if it looks at politics as an arena of selfrealization, and that aesthetic (or, especially, musical) production is in fact the true region of activity in which humanity can at least indicate the possibility of substantial freedom. In this line of thinking, in fact, music might be seen to possess a character which is in some ways analogous to law. Like law, music also forms a formally closed, or even originally hieratic system of terms, which is nonetheless susceptible to gradual reformulation, and in which an originally metaphysical vocabulary might be deployed to articulate human forms of authenticity.

Secondly, a further possible conclusion on these issues would be to say simply that Kant was right all along: that political legitimacy, if not determined simply as coercion, is only possible on the ground of a metaphysical conception of the possibilities of human agency. Following this view, it would be necessary to conclude that the attempt to inscribe in politics a capacity which might autonomously produce a legitimate basis for law is not sustainable. The validity of political action would thus only exist in the extent to which politics is functionally or ethically limited by other categories of justification. The acceptance of this argument would, on some fundamental level, require a denial that politics forms a privileged region of human agency, a rejection of political praxis as a distinct locus of free human self-realization, and a categorization of politics as a technical facility of execution. Underlying this acceptance would be an assertion that human praxis and cognition must be kept distinct, and that human praxis can only assume legitimate authority if it is limited by prior, ethically reflected obligations.

A third conclusion might be an argument for the contextual determinacy of law, close in different ways to Heidegger, Lukács, Schmitt (at times) and Luhmann, which would refuse to acknowledge the centrality of normatively reflected law to legitimacy, and which would be prepared to sanction historically mediated form as the foundation of legitimate order. 
This argument - insofar as it is directly vocalized - usually runs in one of three directions. Firstly, Heidegger and Lukács claim in a paradigmatic manner that political order does not derive its legitimacy from law, but rather from a way of post-juridical knowing. They thus identify the basis of order in an integrally historicized unity of human consciousness, in which the practical justification for order is always already given by the cognitive reality of its constituents. Secondly, Schmitt at times argues that order is determinately legitimate simply on the basis of the normativity of the factical: that all order is simply legitimate qua order. Thirdly, Luhmann like Arnold Gehlen before him - also argues that law is a mere formal device, which guarantees and stabilizes the operative basis of the distinct systems and sub-systems which make up 'society'. All such perspectives, however, might be called upon to admit that their overcoming of the metaphysical basis of politics is fictitious, and that, in diverse manner, they all resurrect the original abstractness of law's metaphysical foundation. Indeed, Heidegger, Lukács, Schmitt (on occasions) and Luhmann might all be seen as thinkers who radicalize the attempt to separate law from metaphysical form to such an extent that they merely reconstitute the original problem of heteronomy in materialized order.

There might, however, also be a fourth conclusion in these questions, which would perhaps draw dialectically on both of these two latter positions. This perspective might, for example, be serious about the basic intent of the anti-metaphysical position on legality and legitimacy; it might sympathize with the hostility toward the Kantian conception of legitimacy as a formal corollary of legality; it might reject the attempt to derive legitimacy from preestablished formal properties; and it might agree that legitimacy requires an epistemological basis which does not construe the mechanics of human thinking on the foundation of a priori universality or formal intelligibility. In this regard, the fourth possible position on these questions might concur with the broad post-Kantian argument that free politicality is in some deep respect bound up with the composition of the human; this view might therefore share the post-Kantian suspicion that Kant's idea of intelligible humanity is not yet free, and not yet human. At the same time, however, this perspective might also recognize that reflections on legitimacy, which allegedly disengage from metaphysical preconditions, usually either integrate originally metaphysical elements as pre-reflexive components of human agency and cognition, or recreate primary metaphysical antinomies in the structures of everyday power and violence.

In other words, this fourth perspective might advocate that the original relation between legality and legitimacy should be revisited and addressed anew, and it might attempt to imagine a relation between law and 
politics in which neither has stable primacy over the other. The greatest challenge, on this view, would be to consider possible relations of legality to legitimacy without formally securing their unity either prior to praxis (in metaphysical or anthropological privilege) or on the grounds of a concrete historical consciousness. This perspective might thus intimate that all the attempts to define a relation between legality and legitimacy, however diverse their intentions, are connected by the assumption that the legitimacy of political order depends on unity: on the Kantian unity of norms, transcendentally deduced prior to politics; on the underlying unity of human character or human reason, variously presupposed by Hegel, Weber, Schmitt and Habermas as the foundation of politics; or on the unity of historically or systemically realized form, which - for Heidegger, Lukács and Luhmann - politics invariably produces. At the risk of oversimplifying, it might be argued that the original problem of law's abstract otherness, presented in theology, metaphysics and the early-modern state, is that law constitutes a series of obligations in unity with a transcendent source, which is at best neutrally and at worst obdurately disposed towards human demands for freedom and self-realization. It is therefore not difficult to reconstruct why anti-metaphysical legal theory should conceive of human self-legislation as a different unity, capable of stating its claims to autonomy and legitimacy against the metaphysical. However, it is at least arguable that this anthropological transition has only succeeded in recreating the false unity of metaphysics in new forms, none of which reliably instate the human as the free author of law. Kant, Hegel, Weber, Schmitt, Habermas, Heidegger and Lukács all imagine human law as the result and form of an anthropological unity of reason, character or history, and all suggest that human-being defines its freedom within such unity. None, however, is able to organize this unitary conception of the human as anything other than secondary metaphysics, or secondary heteronomy.

Against this background, consequently, this fourth perspective might raise the question of whether in the critique of metaphysics the opposition to the imposition of heteronomous dictates on human politics has not been falsely posed, and whether the attempt to explicate the law of humanity has not based itself on misguided preconditions. It is arguable, in fact, that the anthropological transition in political philosophy has neglected to observe that metaphysics contains certain invaluable insights: namely, that legitimate law is not a realized moment of order in the existing conditions of human character or human politics, that the unity of humanity with its own founding principles cannot be invariably invoked as an existing basis for legitimate law, and that the legitimacy of law always reflects an unrealized condition of knowledge and ethics which cannot be transformed directly 
into a pattern for good order. The unfreedom of metaphysical law might thus also, in however dialectical manner, be seen to contain a condition of freedom, which can imagine legitimacy as the deferral of the human, but which rejects the postulation of the human as an already-instituted unity of ethics and cognition upon which static legal prescriptions might be based. On the basis of these considerations, therefore, this last position might understand itself as a dialectical re-evaluation of metaphysical theories of law. It might reassess the metaphysical foundations of modern political philosophy, and argue that the course of political self-liberation from metaphysics could have been more productively undertaken if the paradoxically emancipatory moment in metaphysics had been recognized, and that the neglect of this moment has actually led to the widespread unwitting re-constitution of metaphysics in politics. On this basis, lastly, this perspective might also observe ironically that, although the original revolt against metaphysics resulted from a demand for freedom in politics against theological and metaphysical heteronomy, freedom and politics might in fact both rely dialectically upon a metaphysical residue as the condition of their own existence.

This last perspective is clearly not a unique argument. Similar views can be found in the early Marx, in the constitutional works of Otto Kirchheimer, in Adorno's negative dialectics and even in Karl Jaspers's negative-hermeneutical reconstruction of idealism. To investigate these would be far beyond the scope of this article. Suffice it to say here that each of these positions envisions political legitimacy as a content of human-being which is interpretable only in the negation of instituted forms of being, not on the basis of a static anthropology.

To conclude, in any case: most recent positions on legality and legitimacy, which celebrate their post-metaphysical autonomy, have commonly allowed the possible metaphysical dimension to human politics to be assimilated into an always-realized, or at least latent, category of the human. In this, each position has replicated metaphysics in a this-worldly form. As a result, each position, most importantly, has managed to envisage the possibility of human self-realization (political legitimacy) even in situations whose objective conditions directly militate against such fulfilment. This problem is most pressing in the case of Habermas, who clearly considers himself a proponent of political justice, and who also shows very profound debts to the variants on classical Marxism intimated by Adorno, Kirchheimer and other thinkers close to him. However, Habermas ultimately adopts a position of relative political compliance, which is content to confer legitimacy even on socio-political orders which are structurally anchored in the universal conditions of wage-labour. On a foundational 
level, this aspect of Habermas's outlook is grounded in the fact that he always sees the originally metaphysical possibility of legitimate legislation as a stable component in human life, which is embedded in plural yet universal form in the common resources and experiences of the human. A theory which refused to allow such pre-reflexive coalescence of the metaphysical and the anthropological would not accede to the concrete acceptance of the legal as legitimate set out by Habermas - to remain silent about Hegel, Weber, Schmitt, Lukács, Heidegger and Luhmann.

Chris Thornhill is Professor in Law at Manchester International Law Centre. He is the author of Political Theory in Modern Germany (Polity, 2000), and of Karl Jaspers: Politics and Metaphysics (2002); and his most recent books are $A$ Sociology of Constitutions (2011) and A Sociology of Transnational Constitutions (2016).

\section{Endnotes}

${ }^{1}$ This article is based on a paper given at a Sussex SPT graduate/faculty seminar in March 2001. It now appears in a substantially rewritten form. I would like to thank all participants in seminar for their very stimulating observations, which I have tried to take into account in reformulating this argument. I would also like to express my thanks to Andrew Chitty and Darrow Schecter for their very detailed discussion of this piece.

${ }^{2}$ Ernst H. Kantorowicz, The King's Two Bodies: A Study in Mediaeval Political Theology (Princeton. NJ: Princeton University Press. 1957), pp. 133-5.

${ }^{3}$ See Johannes Heckel, 'Lex charitatis: Eine Untersuchung über das Recht in der Theologie Martin Luthers,' in Abhandlungen der Bayerischen Akademie der Wissenschaften, philosophisch-historische Klasse, new series, vol. 36 (Munchen: Beck. 1953), p. 59.

${ }^{4}$ Immanuel Kant, Kritik der reinen Vernunft [Critique of Pure Reason], in Werke ed. Wilhelm Weischedel. in 6 vols. (Darmstadt: Wissenschaftliche Buchgesellschaft, 1966), vol. II, pp. 327-340.

${ }^{5}$ Martin Heidegger, Kant und das problem der Metaphysik [Kant and the Problem of Metaphysics], in Gesamtausgabe, vol. 3, ed. Fr. W. von Hennann (Frankfurt am Main.: Klostermann, 1990), esp. p. 205. 
${ }^{6}$ Kant, Kritik der reinen Vernunft, p. 706.

${ }^{7}$ Ibid. pp. 489-91.

${ }^{8}$ Ibid. p. 604.

${ }^{9}$ Ibid. p. 679.

${ }^{10}$ Immanuel Kant, Die Metaphysik der Sitten [Metaphysics of Morals], Werke vol. IV, pp. 303-634; 431.

${ }^{11}$ Ibid. p. 424.

${ }^{12}$ See Hans Kiefner, 'Der Einfluß Kants auf Theorie und Praxis des Zivilrechts im 19. Jahrhundert,' in Jürgen Blühdorn and Joachim Ritter (eds.), Philosophie und Rechtswissenschaft. Zum Problem ihrer Beziehung im 19. Jahrhundert (Frankfurt am Main: Klostermann, 1969), pp. 3-25.

${ }^{13}$ Kant, Die Metaphysik der Sitten, p. 366.

${ }^{14}$ Kant, Kritik der reinen Vernunft, p. 674.

${ }^{15}$ Immanuel Kant, Zum ewigen Frieden, in Werke, Vol. 6, pp. 195-251; 241.

${ }^{16}$ On these relations between pure and practical reason, see Susan Neiman, The Unity of Reason: Rereading Kant (Oxford: Oxford University Press, 1994), p. 128; Henry E. Allison, Kant's Theory of Freedom (Cambridge: Cambridge University Press, 1990), p. 51.

${ }^{17}$ Heidegger, Kant und das Problem der Metaphysik, p. 158.

${ }^{18}$ See Kant's own reflections on the 'illusion' of reason in Kritik de reinen Vernunft, p. 706.

${ }^{19}$ See Martin Grabman, 'Studien über den Einfluß der aristotelischen Philosophie auf die mittelalterlichen Theorien über das Verhältnis von Kirche und Staat,' in Sitzungsberichte der philosophisch-hisorischen Abteilung der Bayerischen Akademie der Wissenschaften (München, 1934), pp. 3-161; esp. 9-14. 
${ }^{20}$ G.W.F. Hegel, Grundlinien der Philosophie des Rechts oder Naturrecht und Staatswissenschaft im Grundrisse [Elements of the Philosophy of Right], in Werke, eds. Eva Moldenhauer and Karl Markus Michel, in 20 vols. (Frankfurt am Main: suhrkamp, 1970), vol. Vll, p. 86.

${ }^{21}$ Ibid. pp. 155-7.

${ }^{22}$ Ibid. p. 407.

${ }^{23}$ Ibid. p. 408.

${ }^{24}$ Ibid. p. 409.

${ }^{25}$ Max Weber, 'Politik als Beruf' [Politics as a Vocation], in Gesammelte politische Schriften, ed. Johannes Winckelmann, fifth edition (Tübingen: J.C.B. Mohr, 1988), pp. 505-60; 551.

${ }^{26}$ Max Weber, Wirtschaft und Gesellschaft. Grundriß der verstehenden Soziologie [Economy and Society], ed. Johannes Winckelmann, fifth edition (Tübingen: J.C.B. Mohr, 1972), p. 513.

${ }^{27}$ Weber, 'Politik als Beruf,' p. 553.

${ }^{28}$ Weber, Wirtschaft und Gesellschaft, p. 141.

${ }^{29}$ Schmitt, Verfassungslehre (Berlin: Duncker und Humblot, 1928), p. 121.

${ }^{30}$ Jürgen Habermas, Strukturwandel der Öffentlichkeit. Untersuchungen zu einen Kategorie der bürgerlichen Gesellschaft [The Structural Transformation of the Public Sphere], with an introduction for the new edition, (Frankfurt am Main: Suhrkamp, 1990), p. 204.

31 Jürgen Habermas, Erkenntnis und Interesse [Knowledge and Human Interests] (Frankfurt am Main: Suhrkamp, 1968), p. 319.

32 Jürgen Habermas, Faktizität und Geltung. Beiträge zur Diskurstheorie des Rechts und des demokratischen Rechtsstaates [Between Facts and Norms] (Frankfurt am Main: Suhrkamp, 1992), p. 366.

${ }^{33}$ G.W.F. Hegel, Grundlinien der Philosophie des Rechts, p. 347. 
${ }^{34}$ Ibid. pp. 398, 473.

${ }^{35}$ Marx actually comes close to diagnosing a false apriorism in Hegel's political philosophy. See Karl Marx, Kritik des Hegelschen Staatsrechts [Critique of Hegel's Doctrine of the State], in Karl Marx and Friedrich Engels, Werke ed. the Institut für Marxismus-Leninismus (Berlin: Dietz, 1956) vol. I, pp. 203-333; see p. 310.

${ }^{36}$ Hegel, Grundlinien der Philosophie des Rechts, p. 489.

${ }^{37}$ Weber, Politik als Beruf, pp. 539-40.

${ }^{38}$ On this, see Chris Thornhill, 'Carl Schmitt after the Deluge,' History of European Ideas, 26 (2001), pp. 225-240; 235.

${ }^{39}$ Schmitt, Verfassungslehre, p. 208.

${ }^{40}$ Ibid. p. 209.

41 Jürgen Habermas, 'Versöhnung durch öffentlichen Vernunftgebrauch,' in Die Einbeziehung des Anderen (Frankfurt am Main: Suhrkamp, 1996), pp. 65-94; 90.

${ }^{42}$ Habermas, Faktizität und Geltung, p. 182.

${ }^{43}$ For a counterposed, though still critical, reading, see Glen Newey, After Politics: The Rejection of Politics in Contemporary Liberal Philosophy (London: Palgrave, 2001), esp. p. 170.

${ }^{44}$ Hegel, Grundlinien der Philosophie des Rechts, pp. 357, 407-8.

${ }^{45}$ Max Weber, 'Wahlrecht und Demokratie in Deutschland,' in Gesammelte politische Schriften, pp. 245-291; 291.

${ }^{46}$ Carl Schmitt, Legalität und Legitimität (Berlin: Duncker und Humblot. 1932), p. 81. For a more extensive treatment of this, see Chris Thornhill, Political Theory in Modern Germany (Cambridge: Polity, 2000), p. 76.

47 Jürgen Habermas, 'Replik auf Beiträge zu einem Symposion der Cardozo Law School,' in Einbeziehung des Anderen, pp. 309-398; 379. 
${ }^{48}$ Habermas, Faktizität und Geltung, p. 366.

${ }^{49}$ Martin Heidegger, Sein und Zeit [Being and Time], sixteenth edition (Tübingen: Niemeyer, 1986), p. 382.

${ }^{50}$ Georg Lukács, Geschichte und Klassenbewußtsein. Studien über Marxistische Dialektik [History and Class Consciousness] (Neuwied; Luchterhand, 1968), pp. 206-7.

${ }^{51}$ Heidegger, Kant und das Problem der Metaphysik, p. 159.

${ }^{52}$ Martin Heidegger, Phänomenologie des religiösen Lebens, in Gesamtausgabe vol. 60, eds. M. von Jung et al. (Frankfurt am Main: Klostermann, 1996), pp. $49,80,115$.

${ }^{53}$ Not, consequently, as John McCormick would have it. See John P. McCormick, Carl Schmitt's Critique of Liberalism: Against Politics as Technology (Cambridge: Cambridge University Press, 1997), pp. 83-117.

${ }^{54}$ Lukács, Geschichte und Klassenbewußtstein, p. 328; Martin Heidegger, 'Über den Humanismus' [Letter on Humanism], in Martin Heidegger, Platons Lehre von der Wahrheit. Mit einem Brief über den Humanismus (Bern: Francke, 1947), pp. 53-119.

${ }^{55}$ See: Martin Heidegger, Der Ursprung des Kunstwerkes [On the Origin of the Work of Art] with an introduction by Hans-Georg Gadamer (Stuttgart: Reclam, 1960), p. 60.

${ }^{56}$ For the at times very striking similarities between Luhmann and Heidegger, especially in the theory of sense-constitution, trust, and the critique of ethical humanism, see Niklas Luhmann, Soziale Systeme. Grundriß einer allgemeinen Theorie (Frankfurt am Main: Suhrkamp, 1984), pp. 283-289. 